\title{
Correction to: Biochar efficiency in copper removal from Haplic soils
}

\author{
A. Tomczyk ${ }^{1}$ (D) P. Boguta ${ }^{1}$ (i) $\cdot$ Z. Sokołowska ${ }^{1}$ (1)
}

Published online: 13 June 2019

(c) The Author(s) 2019

\section{Correction to: \\ International Journal of Environmental Science and Technology https://doi.org/10.1007/s13762-019-02227-4}

The article listed above was initially published with incorrect copyright information. Upon publication of this correction, the copyright of this article changed to "The Author(s)". The original article have been corrected.

Open Access This article is distributed under the terms of the Creative Commons Attribution 4.0 International License (http://creativeco mmons.org/licenses/by/4.0/), which permits unrestricted use, distribution, and reproduction in any medium, provided you give appropriate credit to the original author(s) and the source, provide a link to the Creative Commons license, and indicate if changes were made.

The original article can be found online at https://doi.org/10.1007/ s13762-019-02227-4.

A. Tomczyk

atomczyk@ipan.lublin.pl

1 Institute of Agrophysics, Polish Academy of Sciences,

Doświadczalna 4, 20-290 Lublin, Poland 